\title{
PENGARUH PENGGUNAAN MODEL COOPERATIVE LEARNING TIPE GROUP INVESTIGATION (GI) TERHADAP HASIL BELAJAR IPS TERPADU KELAS VIII SEMESTER GENAP SMPYPI 1 BANDAR MATARAM LAMPUNG TENGAH T.P 2015/2016
}

\author{
Desi Fatmawati ${ }^{1)}$ Maryatun ${ }^{2)}$ \\ Program Studi Pendidikan Ekonomi FKIP Universitas Muhammadiyah Metro \\ maryatunsukanso@gmail.com
}

\begin{abstract}
Abstrak
Metode cooperative learning tipe group investigation merupakan model pembelajaran kooperatif yang dapat melibatkan peserta didik secara aktif dalam kegiatan pembelajaran mulai dari merencanakan topik-topik yang akan dipelajari, bagaimana melaksanakan investigasinya, hingga melakukan presentasi kelompok dan evaluasi. Tujuan penelitian ini adalah untuk mengetahui adanya pengaruh penggunaan model pembelajaran cooperative learning tipe Group Investigation terhadap hasil belajar IPS Terpadu peserta didik kelas VIII semester genap SMP YPI 1 Bandar Mataram Lampung Tengah tahun pelajaran 2015/2016. Hipotesis yang penulis ajukan adalah "Ada pengaruh yang positif pada model pembelajaran cooperative learning tipe Group Investigation terhadap hasil belajar IPS Terpadu peserta didik kelas VIII semester genap SMP YPI 1 Bandar Mataram Lampung Tengah tahun pelajaran 2015/2016. Populasi dalam penelitian ini adalah siswa kelas VIII SMP YPI 1 Bandar Mataram Lampung Tengah Tahun Pelajaran 2015/2016 yaitu berjumlah 48 orang siswa dan diantaranya terdiri dari 2 kelas. Dan yang menjadi sampel dalam penelitian ini adalah kelas VIIIa dan VIIIb. Kelas VIIIa sebagai kelas eksperimen dan kelas VIIIb sebagai kelas control, sampel diambil menggunakan teknik purposive sampling, Eksperimen dilaksanakan pada siswa kelas VIIIa Semester Genap SMP YPI 1 Bandar Mataram Lampung Tengah Tahun Pelajaran 2015/2016 yang berjumlah 24 peserta didik. Data penelitian ini dikumpulkan dengan menggunakan metode observasi, wawancara, dokumentasi, dan tes. Sedangkan untuk mengetahui tingkat validitas dan reliabilitas penulis menggunakan rumus K-R 20. Kemudian untuk menguji/membuktikan hipotesis digunakan rumus Regresi Linier Sederhana yaitu $\hat{\mathbf{Y}}=\mathbf{a}+\mathbf{b x}$. Nilai $\hat{\mathbf{Y}}=73,33+0,5 \mathrm{X}$ yang dilanjutkan dengan rumus $\mathrm{t}_{\text {hitung }}>$

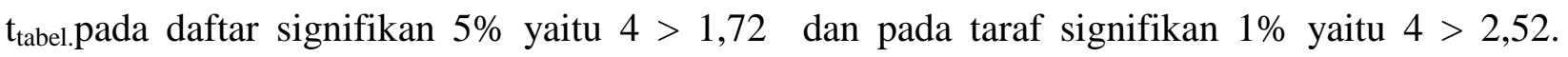
Dengan demikian hipotesisnya diterima karena ada pengaruh yang positif terhadap penggunaan model pembelajaran cooperative learning tipe Group Investigation terhadap hasil belajar IPS Terpadu SMP YPI 1 Bandar Mataram Lampung Tengah.

Kata kunci: Model Pembelajaran cooperative learning tipe Group Investigation, Hasil Belajar
\end{abstract}

PENDAHULUAN

Pendidikan merupakan salah satu faktor penting dalam perkembangan dan pembangunan suatu negara. Negara dikatakan maju dalam segala bidang baik dalam bidang ekonomi, teknologi, pertaniaan

Jurnal Pendidikan EKonomi UM Metro 
ataupun yang lainnya tidak terlepas dari peran pendidikan. Hal ini dikarenakan orang cerdas atau berpendidikan akan dapat memberikan kontribusi yang positif kepada negara. Akan tetapi yang perlu diingat bahwa pendidikan akan berhasil dengan maksimal mana kala setiap elemen dari pendidikan baik dari bawah sampai atas senantiasa berorientasi pada tujuan pendidikan nasional.

Menurut Juhri (2010:11) mengatakan bahwa:

Pendidikan adalah sesuatu yang universal dan belangsung terus tak terputus dari suatu generasi ke generasi berikutnya, di mana pun di dunia ini. Upaya memanusiakan manusia melalui kegiatan yang diselenggarakan sesuai dengan pandangan hidup dan dalam latar sosial-kebudayaan setiap masyarakat tertentu. Oleh karena itu, meskipun pendidikan itu bersifat universal, namun terjadi perbedaanperbedaan tertentu sesuai dengan pandangan hidup dan latar sosiokultural setiap manusia. Dengan kata lain, pendidikan diselenggarakan berlandaskan filsafat hidup serta berlandaskan sosiokultur setiap masyarakat, termasuk di Indonesia.

Terkait dengan tujuan pendidikan itu sendiri adalah membentuk sumber daya manusia yang berkualitas tinggi agar menjadi manusia yang beriman dan bertakwa kepada Tuhan Yang Maha Esa yang mampu menghadapai perkembangan zaman dengan dibantu peran dari seorang guru dalam mendidik kemampuan intelegensi dan moral anak.

Seorang peserta didik dikatakan telah mencapai perkembangannya secara optimal apabila peserta didik dapat memperoleh pendidikan dan prestasi belajar yang sesuai dengan bakat, kemampuan dan minat yang dimilikinya. Terkait dengan dunia pendidikan, untuk menciptakan manusia yang berkualitas dan berprestasi tinggi maka peserta didik harus memiliki hasil belajar yang baik. Hasil belajar merupakan tolak ukur maksimal yang telah dicapai peserta didik setelah melakukan perbuatan belajar selama waktu yang telah ditentukan bersama.

\section{SMP YPI 1 Bandar Mataram} Lampung Tengah merupakan salah satu sekolah swasta yang mempunyai input atau masukan hasil belajar Peserta didik yang bervariasi, maka peneliti menggunakan model pembelajaran cooperative dalam pembelajran karena Peserta didik disekolah tersebut kurang aktif dalam belajar, dan masih kurang memperhatikan guru krtika menyampaikan pelajaran. Dengan penggunaan model pembelajaran cooperative ini siswa akan di tuntut untuk aktif dalam belajar sehingga tujuan pembelajran akan tercapai. 
Menurut hasil pengamatan yang dilakukan peneliti pada saat survei melalui observasi kelas dan wawancara dengan guru mata pelajaran IPS Terpadu kelas VIII Semester Genap di SMP YPI 1 Bandar Mataram Lampung Tengah tahun pelajaran 2015/2016 menunjukkan bahwa pencapaian kompetensi mata pelajaran IPS Terpadu kurang optimal. Asumsi dasar yang menyebabkan pencapaian kompetensi pelajaran IPS Terpadu.

Berdasarkan data survei presentase hasil belajar peserta didik masih rendah, hal ini terlihat dari peserta didik yang tuntas hasil belajarnya mencapai KKM sebanyak 4 peserta didik atau 16,6\%,dan peserta didik yang belum tuntas sebanyak 20 peserta didik atau $83,3 \%$. Hal ini masih jauh dari apa yang diharapkan. Berdasarkan latar belakang diatas perlu dicari solusinya untuk mengatasi permasalahan tersebut yaitu dengan menerapkan salah satu model pembelajaran Cooperative Learning Tipe Group Investigation $(G I)$. Dengan menggunakan tipe Goup investigasi ini diharapkan peserta didik bisa lebih aktif dan efektif dalam belajar sehingga akan meningkatkan hasil belajar peserta didik.

\section{KAJIAN PUSTAKA}

\section{TipeGroup Investigation (GI)}

Group Investigation merupakan salah satu bentuk model pembelajran kooperatif yang menekankan pada partisipasi dan aktivitas siswa untuk mencari sendiri materi (informasi) pelajaran yang akan dipelajari melalui bahan-bahan yang tersedia, missalnya dari buku atau dari internet. Siswa dilibatkan sejak perencanaan, baik dalam menentukan topic maupun cara untuk mempelajarinya melalui investigasi. Tipe ini menuntut para siswa untuk memiliki kemampuan yang baik dalam berkomunikasi maupun dalam ketrampilan proses kelompok. Model Group Investigation dapat melatih siswa untuk menumbuhkan kemampuan berfikir mandiri. Keterlibatan siswa secara aktif dapat terlihat melalui tahap pertama sampai akhir pembelajaran. Adapun pengertian Group Investigation menurut Rusman (2012:123)

Strategi belajar kooperatifGI dikembangkan oleh Sholomo Sharan dan Yael Sharan di Universitas Tei Aviv, Israel. Secara umum peranan perencanaan pengorganisasian kelas dengan menggunakan teknik kooperativeGroup Investigation $(G I)$ adalah kelompok dibentuk oleh peserta didik itu sendiri dengan beranggotakan 2-6 orang, tiap kelompok bebas memilih subtopik dari keseluruhan unit materi (pokok bahasan) yang akan diajarkan, dan kemudian membuat atau menghasilkan laporan kelompok. Selanjutnya setiap kelompok memamerkan atau mempresentasikan laporannya kepada seluruh kelas, untuk 
berbagi dan saling bertukar informasi temuan mereka.

MenurutKurniasih (2015:71) Group Investigation adalah:"Salah satu bentuk model pembelajaran kooperatif yang memiliki titik tekan padap artisipasi dan aktivitas siswa untuk mencari sendiri materi atau segala sesuatu mengenai materi pelajaran yang akan dipelajari”.

Berdasarkan pada pendapat para ahli, maka dapat diambil disimpulkan bahwa model cooperative learning tipe group investigation merupakan model pembelajaran cooperative yang melibatkan peserta didik secara maksimal dalam kegiatan pembelajaran mulai dari merencanakan topik-topik yang akan dipelajari, bagaimana melaksanakan investigasinya, hingga melakukan presentasi kelompok dan evaluasi. Model ini menekankan pada partisipasi dan aktivitas peserta didik untuk mencari sendiri materi (informasi) pelajaran yang akan dipelajari melalui bahan-bahan yang tersedia, misalnya dari buku pelajaran atau peserta didik dapat mencari melalui internet. Penerapan model investigasi kelompok pada pembelajaran diperlukan keterampilan berkomunikasi yang baik antar peserta didik untuk memperlancar jalannya proses kelompok, sehingga sebelum melakukan investigasi kelompok guru diharapkan memberikan pelatihan-pelatihan berkomunikasi kepada peserta didik.

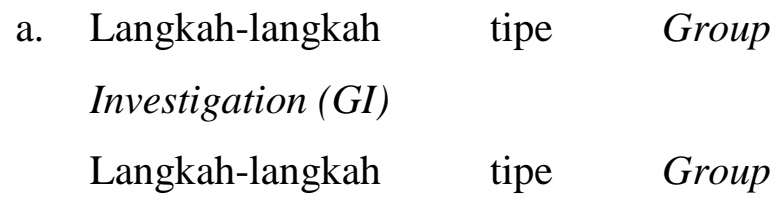

Investigation (GI) sebagai berikut:

Tabel 2.Tahap-tahap kemajuan peserta didik dalam menggunakan model pembelajaran Cooperative Learning tipe Group Investigation.menurut Kurniasih (2015:74)

\begin{tabular}{|c|c|}
\hline $\begin{array}{c}\text { Tahap I } \\
\text { Menyeleksi topik }\end{array}$ & $\begin{array}{l}\text { Tahap pertama siswa memilih berbagai } \\
\text { subtopik dalam materi yang akan dipelajari } \\
\text { atau dari gambaran yang diberikan oleh } \\
\text { guru.Kemudian mengorganisir siswa menjadi } \\
\text { kelompok-kelompok yang berorintasi pada } \\
\text { tugas yang beranggotakan } 2 \text { hingga } 6 \text { orang }\end{array}$ \\
\hline $\begin{array}{c}\text { Tahap II } \\
\text { Merencanakan Kerjasama }\end{array}$ & $\begin{array}{l}\text { Bersama-sama dengan siswa, guru } \\
\text { merencanakan berbagai prosedur belajar, } \\
\text { tugas dan tujuan umum yang konsisten } \\
\text { dengan berbagai topic dan subtopik yang }\end{array}$ \\
\hline
\end{tabular}




\begin{tabular}{|c|c|}
\hline & telah dipilih dari langkah 1 diatas.; \\
\hline $\begin{array}{c}\text { Tahap III } \\
\text { Pelaksanaan }\end{array}$ & $\begin{array}{l}\text { Para siswa melaksanakan rencana yang telah } \\
\text { dirumuskan pada langkah (merencanakan } \\
\text { kerjasama) di atas. Proses pelaksanaan } \\
\text { melibatkan berbagai aktivitas dan } \\
\text { ketrampilan dengan variasi yang luas dan } \\
\text { mendorong para siswa untuk menggunakan } \\
\text { berbagai sumber baik yang terdapat di dalam } \\
\text { maupun di luar sekolah. Dan guru harus } \\
\text { memastikan setiap kelompok tidak } \\
\text { mengalami kesulitan. }\end{array}$ \\
\hline $\begin{array}{c}\text { Tahap IV } \\
\text { Analisis dan sintesis }\end{array}$ & $\begin{array}{l}\text { Para siswa menganalisis dan mensintesis } \\
\text { berbagai informasi yang diperoleh pada } \\
\text { langkah (pelaksanaan) dan merencanakan } \\
\text { agar dapat diringkaskan dalam suatu } \\
\text { penyajian yang menarik di depan kelas.. }\end{array}$ \\
\hline $\begin{array}{c}\text { Tahap V } \\
\text { Penyajian hasil akhir }\end{array}$ & $\begin{array}{l}\text { Dengan pengawasan guru, setiap kelompok } \\
\text { mempresentasikan berbagai topik yang telah } \\
\text { dipelajari agar semua siswa dalam kelas } \\
\text { saling terlibat dan mencapai suatu perspektif } \\
\text { yang luas mengenai topik tersebut.. }\end{array}$ \\
\hline $\begin{array}{c}\text { Tahap VI } \\
\text { Melakukan evaluasi }\end{array}$ & $\begin{array}{l}\text { Bersama-sama siswa, guru melakukan } \\
\text { evaluasi mengenai kontribusi tiap kelompok } \\
\text { terhadap pekerjaan kelas sebagai suatu } \\
\text { keseluruhan. Evaluasi dapat mencakup tiap } \\
\text { siswa secara individu atau kelompok, atau } \\
\text { keduanya. }\end{array}$ \\
\hline
\end{tabular}


1. KelebihandankekuranganGroup Investigation (GI)

Model pembelajaran pada hakekatnya memiliki kekurangan dan kelebihan menurut Kurniasih (2015:73) adalah sebagai berikut:

a. Kelebihan Group Investigation (GI)

1. Model pembelajaran Group Investigation memliki dampak positif dalam meningkatkan prestasi belajar siswa.

2. Penerapan model ini mempunyai pengaruh positif, yaitu dapat meningkatkan motivasi belajar siswa.

3. Pembelajaran yang dilakukan membuat suasana saling bekerjasama dan berinteraksi antar siswa dalam kelompok tanpa memandang latar belakang.

4. Model ini juga melatih siswa untuk memiliki kemampuan yang baik dalam berkomunikasi dan mengemukakan pendapatnya.

5. Memotivasi dan mendorong siswa agar aktif dalam proses belajar mulai dari tahap pertama samapi tahap akhir pembelajaran.

b. Kekurangan Group Investigation (GI)

1. Model pembelajaran group investigation merupakan model pembelajaran yang kompleks dan sulit untuk dilaksanakan dalam pembelajaran kooperatif.

2. Model ini membutuhkan waktu yang lama.

Berdasarkan pendapat diatas dapat diambilpengertianbahwa metode $G I$ merupakan salah satu model pembalajaran kooperatif, di mana pembelajaran GI ini memberikan keuntungan bagi peserta didik yang berkemampuan rendah, sedang dan tinggi. Penggunaan model pembelajaran GI diharapkan peserta didik bisa lebih aktif dalam proses pembelajaran karena model pembelajaran ini lebih menekankan keterlibatan peserta didik yang akan nampak dari awal hingga akhir dan hasil belajar peserta didik akan meningkat.

\section{Hasil Belajar}

Hasil belajar merupakan suatu hal yang diperoleh peserta didik setelah mengikuti kegiatan proses pembelajaran berdasarkan kriteria tertentu dalam pengukuran pencapaian tujuan pembelajaran itu sendiri yang dapat memberikan perubahan tingkah laku baik pengetahuan, pemahaman, sikap dan keterampilan peserta didik sehingga menjadi lebih baik dari pada sebelumnya. Sebagaimana yang dikemukankan Sudjana (2012:3) sebagai berikut:

Hasil belajar pada hakikatnya adalah perubahan tingkah laku seperti telah dijelaskan dimuka. Tingkah laku 
sebagai hasil belajar dalam pengertian yang luas mencakup bidang kognitif, afektif, dan psikomotorik. Oleh sebab itu dalam penilaian hasil belajar,peranan tujuan intruksional yang berisi rumusan kemampuan dan tingkah laku yang diinginkan dikuasai siswa menjadi unsur penting sebagai dasar dan acuan penilaian.

Menurut Yusuf (2015:181) menyatakan

bahwa:

Hasil belajar merupakan wujud pencapain peserta didik; sekaligus merupakan lambang keberhasilan pendidik dalam membelajarkan peserta didik. Tes hasil belajar (Achievement test), kadang-kadang disebut juga tes prestasi belajar, merupakan salah satu alat yang dapat digunakan pendidik di sekolah atau pendidik di lembaga pendidikan tinggi, untuk memahami tingkat keberhasilan peserta didik dalam belajar.

Berdasarkan pendapat para ahli dapat diambil pengertian bahwa hasil belajar yang dimaksudkan dengan penelitian ini adalah hasil yang dicapai oleh peserta didik setelah melakukan proses pembelajaran. Hasil belajar tersebut dapat berupa pengetahuan dalam penguasaan sejumlah materi pelajaran, dan dapat pula disimbolkan dengan grade atau skor. Pada akhir proses pembelajaran, dilakukan evaluasi tes untuk melihat hasil belajar peserta didik. Dari angka yang diperoleh peserta didik tersebut dapat ditentukan apakah peserta didik tersebut sudah tuntas belajar atau belum. Untuk mencapai keberhasilan peserta didik dalam proses pembelajaran dapat dilihat dari seberapa besar tercapainya hasil belajar yang dapat diketahui setelah peserta didik tersebut mengalami proses pembelajaran dan umumnya diwujudkan dengan pemberian nilai berupa angka-angka dan huruf-huruf. Hasil belajar yang dimaksud dalam penelitian ini adalah hasil belajar yang berupa angka, sehingga besar kecilnya hasil belajar yang diperoleh menunjukkan berhasil tidaknya proses-proses pembelajaran yang telah dilakukan.

Penjelasan di atas mengungkapkan bahwa belajar adalah perubahan tingkah laku dalam diri seseorang yang disebabkan adanya pengalaman. Menurut Karwono dan Mularsih (2010:35) faktor-faktor yang mempengaruhi hasil belajar dapat diuraikan sebagai berikut:

1) Faktor Internal, adalah faktor yang mengelola dan memproses lingkungan sehingga menghasilkan perubahan tingkah laku sebagai hasil belajar, karakteristik masing-masing individu berbeda satu dengan yang lainnya. Maka masing-masing individu akan merespon terhadap faktor yang ada diluar dirinya (lingkungan) dengan cara yang berbeda- 
beda, yang termasuk dalam faktor internal adalah:

i. Faktor Jasmaniah :Kesehatan, cacat Tubuh

ii. Faktor Psikologi :Intelegensi, perhatian, minat, bakat, motivasi, kematangan dan kesiapan.

2) Faktor Eksternal, adalah segala sesuatu yang ada diluar diri individu atau disebut juga lingkungan. Pola interaksi individu dengan lingkungan yang menghasilkan perubahan tingkah laku, yang termasuk dalam faktor eksternal adalah:

i. Lingkungan fisik antara lain terdiri atas: geografis ,rumah, sekolah, tempat bermain, dan sebagainya.

ii. Lingkungan psikis : aspirasi, harapan, cita-cita, dan masalah.

iii. Lingkungan personal : teman sebaya, orang tua, guru, dan seterusnya.

iv. Lingkungan non personal: rumah, peralatan, pepohonan dan sebagainya.

Dari pendapat diatas maka dapat disimpulkan bahwa yang mempengaruhi factor belajar terdapat dua factor yaitu faktor internal dan factor eksternal. Dimana kedua factor ini sangat bepengaruh penting terhadap peserta didik. Faktor internal berpengaruh terhadap tingkat kematangan atau kecerdasan yang dimiliki setiap individu dan tidak semua kecerdasan yang dimiliki satu individu akan sama dengan individu yang lainnya. Faktor internal disisni lebih cenderung pada factor lingkungan yang sangat berpengaruh terhadap karakter peserta didik Karena dalam factor eksternal menyangkut teman sebaya, orang tuadan guru.

\section{METODE PENELITIAN}

Rencana yang akan dilakukan dalam penelitian ini bersifat kuantitatif yang bertujuan untuk meningkatkan hasil belajar IPS Terpadupada peserta didik. Pada penelitian ini jenis penelitian yang akan dilakukan adalah pengaruh, dimana penelitian menggunakan model pembelajaran Cooperative Learning Tipe Group Investigation. Adapun proses pelaksanaannya nanti akan diberikan pendalaman teori terlebih dahulu.

Metode eksperimen dalam penelitian ini yang digunakan adalah metode eksperimen True exsperimental design denganbentukPretest- Posttest Control Group Design. Kemudian setelah akhir pokok bahasan diadakan test eksperimen sebagai metode dalam mengumpulkan data. Dari data yang diambil rata-rata kemudian diambil sebagai ukuran hasil belajar dalam penguasaan materi IPS Terpadusemester 
Genap. Bentuk soal dan telah yaitu pemilihan sampel dengan dipertimbangkan tingkat kesukarannya untuk pertimbangan tertentu,dalam pengambilan tiap item.

Populasi adalah sekelompok peserta didik yang akan dijadikan objek pengamatan penelitian. Dalam penelitian ini populasinya adalahseluruhkelas VIII SMP YPI 1 Bandar Mataram Lampung Tengah TahunPelajaran $2015 / 2016$ yang terdiridariduakelasyaitukelas $\quad$ VIII A sampel yaitu dengan menuliskan kelas dan jumlah peserta didik untuk kemudian diobservasi dan dijadikan sebagai sampel penelitian. Sehingga diperoleh bahwa kelas VIII A yang berjumlah 24 peserta didiksebagai kelas eksperimen. dan kelas VIII B yang berjumlah 24 sebagai kelas dankelas VIII B dengan jumlah 48 peserta didik,yang terdiri dari: kelas VIII A berjumlah 24 siswadan VIII B berjumlah 24 siswa.

Menurut Sugiyono (2013:118) sampel adalah bagian dari jumlah dan karakteristik yang dimiliki oleh populasi tersebut.peneliti menggunakan teknik sampling purposive control.

\section{PEMBAHASAN HASIL PENELITIAN}

Berdasarkan nilai-nilai dari hasil belajar IPS Terpadu siswa dari evaluasi uji pretest ataupun posttest, setelah diberikan treatment model pembelajaran kooperatif tipe Group Investigation dapat dilihat pada tabel berikut:

Tabel 20.Presentase hasil belajar IPS terpadu pada siswa kelas VIII A Semester Genap di SMP YPI 1 Bandar Mataram Tahun Pelajaran 2015/2016.

\begin{tabular}{|c|c|c|c|c|c|c|}
\hline \multirow{2}{*}{ No } & \multirow{2}{*}{$\begin{array}{c}\text { Interval } \\
\text { Nilai }\end{array}$} & \multirow{2}{*}{ Kategori } & \multicolumn{2}{|c|}{ Evaluasi uji pre test } & \multicolumn{2}{|c|}{$\begin{array}{c}\text { Evaluasi Uji } \\
\text { Posttest }\end{array}$} \\
\cline { 4 - 7 } & & & $\begin{array}{c}\text { Jumlah } \\
\text { Siswa }\end{array}$ & Presentase & $\begin{array}{c}\text { Jumlah } \\
\text { Siswa }\end{array}$ & Presentase \\
\hline 1 & $\geq 74$ & Tuntas & 4 & 16,67 & 15 & 62,5 \\
\hline 2 & $<74$ & $\begin{array}{c}\text { Belum } \\
\text { Tuntas }\end{array}$ & 20 & 83,33 & 9 & 37,5 \\
\hline & \multicolumn{2}{|c|}{ Jumlah } & & & & 100 \\
\hline
\end{tabular}

Sumber: Hasil belajar IPS terpadu siswa kelas VIII A Semester Genap di SMP YPI 1 Bandar Mataram dari hasil penelitian 
Berdasarkan tabel di atas dapat diketahui bahwa pada tahap evaluasi uji pretest, bahwa siswa yang mencapai tuntas belajar hanya $16,7 \%$ (4 siswa), sedangkan siswa yang belum mencapai tuntas belajar adalah 83,3\% (20 siswa), dengan demikian dapat di temukan bahwa jumlah siswa yang belum tuntas belajar atau belum mencapai standar ketuntasan yang telah ditetapkan masih banyak yaitu 83,33\% atau 20 siswa dari total keseluruhan siswa sebanyak 24 siswa dan tabel di atas dapat menunjukkan juga bahwa pada tahap evaluasi uji posttest, setelah siswa mendapatkan treatment atau perlakuan penggunaan model pembelajaran kooperatif tipe Group Investigation yang mencapai tuntas belajar berjumlah $62,5 \%$ (15 siswa), sedangkan siswa yang belum mencapai tuntas belajar berjumlah 37,5\% (9 siswa), dari total keseluruhan siswa sebanyak 24 siswa.

Setelah siswa mendapatkan treatment atau perlakuan model pembelajaran kooperatif tipe Group Investigation hasil belajar IPS terpadu mengalami peningkatan dilihat dari evaluasi pretest dan evaluasi posttest, yaitu siswa yang mencapai kriteria ketuntasan minimal pada evaluasi pretest adalah $16,7 \%$ atau 4 siswa dari total keseluruhan siswa 24 siswa, sedangkan siswa yang mencapai kriteria ketuntasan

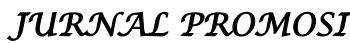
Jurnal Pendidikan Ekonomi UM Metro minimal pada evaluasi posttest adalah $62,5 \%$ atau 15 siswa, dari total keseluruhan siswa sebanyak 24 siswa.

Secara keseluruhan bahwa setelah siswa mendapatkan treatment, perlakuan penggunaan model pembelajaran kooperatif tipe Group Investigation hasil belajar IPS Terpadu mengalami peningkatan, karena penggunaan model pembelajaran kooperatif tipe Group Investigation ini menekankan siswa lebih aktif dalam proses pembelajaran. Berdasarkan analisis data hasil belajar IPS Terpadu diperoleh hasil penelitian yang sesuai dengan rumusan masalah dan tujuan penelitian yaitu sebagai berikut:

Berdasarkan perhitungan dengan rumus regresi linier sederhana dengan menggunakan $t_{\text {hitung }}\left(t_{o}\right)$ dalam analisis data dapat diketahui bahwa analisis perhitungan nilai tersebut $t_{\text {hitung }}>t_{\text {tabel }}$. Pada taraf signifikan 5\% yaitu $4>1,72$ yaitu $t_{\text {hitung }}$ lebih besar 2,28 dari $t_{\text {tabel }}$ dan pada taraf signifikan $1 \%$ yaitu $4>2,52$ yaitu $t_{\text {hitung }}$ lebih besar 1,48 dari $t_{\text {tabel }}$. Jika $t_{\text {tabel dengan }} t_{\text {hitung }}>t_{\text {tabel }}$ berarti hipotesisnya diterima. Dan apabila $t_{\text {hitung }}<t_{\text {tabel }}$ berarti hipotesisnya ditolak.

Dengan demikian, pengaruh penggunaan model pembelajaran Kooperatif 
tipe Group Investigation terhadap hasil belajar IPS Terpadu peserta didik Kelas VIII Asemester genap SMP YPI 1 Bandar Mataram tahun pelajaran 2015/2016 hipotesisnya dapat diterima/ dibuktikan.

\section{KESIMPULAN}

Berdasarkan penelitian yang dilakukan oleh penulis maka dapat disimpulkan bahwa pada tahap evaluasi uji pretest, siswa yang mencapai tuntas belajar hanya $16,7 \%$ (4 siswa), sedangkan siswa yang belum mencapai tuntas belajar adalah 83,3\% (20 siswa), dengan demikian dapat di temukan bahwa jumlah siswa yang belum tuntas belajar atau belum mencapai standar ketuntasan yang telah ditetapkan masih banyak yaitu $83,3 \%$ atau 20 siswa dari total keseluruhan siswa sebanyak 24. Dan pada tahap evaluasi uji posttest, setelah siswa mendapatkan treatment atau perlakuan penggunaan model pembelajaran kooperatif tipe Group Investigation (GI)yang mencapai tuntas belajar berjumlah 62,5\% (15 siswa), sedangkan siswa yang belum mencapai tuntas belajar berjumlah 37,5\% (9 siswa), dari total keseluruhan siswa sebanyak 24 siswa.

Pada pengujian dengan menggunakan rumus Regresi Linier Sederhana diperoleh a $=73,33, \mathrm{~b}=0,5$, sehingga dengan demikian
$\hat{Y}=a+b X$, adalah $\hat{\mathrm{Y}}=73,33+0,5 \mathrm{X}$. Kemudian, dari hasil analisis yang dilakukan maka terbukti bahwa ada pengaruh yang positif penggunaan model pembelajaran kooperatif tipe Group Investigation terhadap hasil belajar IPS Terpadu pada peserta didik kelas VIII A SMP YPI 1 Bandar Mataram Lampung Tengah. Hal ini dibuktikan dengan penghitungan analisis data dapat diketahui bahwa nilai tersebut $t_{\text {hitung }}>t_{\text {tabel }}$, dan terlihat bahwa pada taraf signifikan $5 \%$ yaitu $4>$ 1,72. Dan pada taraf signifikan $1 \%$ yaitu 4 $>2,52$, yang dapat dilihat pada daftar $G$ tabel statistik. Dengan demikian maka hipotesis diterima, bahwa ada pengaruh positif penggunaan model pembelajaran kooperatif tipe Group Investigation (GI) terhadap hasil belajar IPS Terpadu kelas VIII A semester genap SMP YPI 1 Bandar Mataram Lampung Tengah tahun pelajaran $2015 / 2016$.

Berdasarkan kesimpulan yang diperoleh selama melaksanakan penelitian dan hasil pengamatan dalam pelaksanaan penelitian, maka penulis menyampaikan saran-saran sebagai berikut:

1) Untuk meningkatkan hasil belajar diharapkan guru menjadi fasilitator dan motivator, sehingga peserta didik menjadi lebih aktif dalam proses 
pembelajaran dan penerapan model cooperative learning tipe Group Investigation diharapkan bisa diterapkan sehingga peserta didik dapat lebih semangat dalam belajar.

2) Model cooperative learning tipe Group Investigation merupakan pembelajaran kooperatif yang melibatkan siswa secara aktif dalam kegiatan pembelajaran mulai dari merencanakan topik yang akan dipelajarai, melaksanakan investigasi, melakukan presentasi sampai dengan tahapa evaluasi. Disini siswa harus aktif dalam pembelajaran, sehingga dapat meningkat kanhasil belajar terutama pada bidang studi IPS Terpadu.

3) Dengan penggunaan penerapan model kooperatif khususnya tipe Garoup Investigation siswa diharapkan saling bekerjasama dan saling menghargai satu sama lain.

4) Untuk meningkatkan hasil belajar diharapkan Sekolah dapat meberikan fasilitas atau sarana agar proses pembelajaran lebih mudah dan efisien.

Dengan empat hal tersebut di atas mudah-mudahan dapat bermanfaat dengan baik untuk meningkatkan hasil belajar peserta didik dalam proses pembelajaran.
Juhri. 2010. Landasan dan Wawasan Pendidikan suatu Pendekatan Kompetensi Guru. Jakarta: Panji Grafika.

Karwono (dkk), 2010. Belajar dan Pembelajaran serta Pemanfaatan Sumber Belajar. Pondok Hijau Ciputat: Cerdas Jaya.

Kurniasih, Imas (dkk). 2015. Model Pembelajaran. Kata Pena

Rusman. 2012. Model-Model Pembelajaran: Mengembangkan Profesionalisme Guru. Jakarta: PT Raja Grafindo Persada. .

Sudjana. 2012. Metode Statistika. Bandung: penerbit Tarsito.

Sugiyono. 2013. Metode Penelitian Kuantitatif, Kualitatif, dan $R \& D$. bandung: Alfabeta.

Yusuf, Muri. 2015. Asesmen dan Evalusi Pendidikan. Jakarta: Kencana, Prenada Media Group.

\section{DAFTAR PUSTAKA}

